\title{
Diamonds and carbonatites in the deep lithosphere: Evidence of genetic links
}

\author{
W.L. Griffin ${ }^{1}$, D. Araujo ${ }^{1}$, S.Y. O'Reilly ${ }^{1}$, S. Rege ${ }^{1}$, E. van Achterbergh ${ }^{2}$ \\ ${ }^{I}$ GEMOC, Dept. Earth \& Planetary Sciences, Macquarie Univ., NSW 2109, Australia \\ ${ }^{2}$ Rio Tinto Technology \& Innovation, 1 Research Ave., Bundoora, VIC 3083, Australia
}

Some diamonds from the A154 kimberlite, in the Lac de Gras area of the Slave Craton, have gem-quality octahedral cores overgrown by porous, fibrous to particulate coats ranging from tens of microns to $\approx 1$ $\mathrm{mm}$ in thickness (Fig. 1).

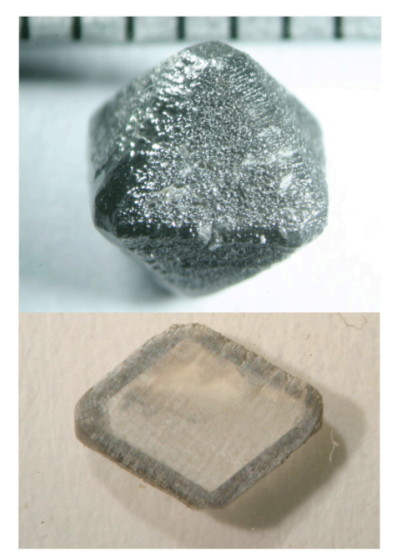

Figure 1. Coated octahedral diamond from A154, whole stone and polished plate.

Quantitative trace-element analysis of the cores and coats by LAM-ICPMS (using methods described by Rege et al. (2005)) shows distinct differences in the composition of the metasomatic fluids/me/ts from which each type of diamond grew.

\section{Diamond Analyses}

The cores have trace-element patterns (Fig. 2) broadly similar to those of monocrystalline diamonds from other localities worldwide. They show LREE depletion $\left.(\mathrm{La} / \mathrm{Nd})_{\mathrm{CN}}<1\right)$, negative $\mathrm{Sr}$ and $\mathrm{Y}$ anomalies relative to $\mathrm{Sm}$ and $\mathrm{Ho}$, respectively, $\mathrm{Ba} / \mathrm{La})_{\mathrm{CN}} \approx 1-3$, $\left.\mathrm{Th} / \mathrm{U})_{\mathrm{CN}} \approx 0.5, \quad \mathrm{Zr} / \mathrm{Hf}\right)_{\mathrm{CN}}$ and $\left.\mathrm{Nb} / \mathrm{Ta}\right)_{\mathrm{CN}}<<1$ and low $\mathrm{Mg} / \mathrm{Ca}$. These trace elements are assumed to reside in submicroscopic fluid and solid (daughter mineral) inclusions, rather than in the diamond lattice.

The coats are typically homogeneous within each stone, and their trace-element patterns are very similar from stone to stone ( $>20$ stones analysed). They have $\mathrm{CN}$ abundances of the HREE similar to those in the monocrystalline diamonds, but show strong LREE enrichment $\left.\left.(\mathrm{La} / \mathrm{Nd})_{\mathrm{CN}} \geq 30\right), \mathrm{Ba} / \mathrm{La}\right)_{\mathrm{CN}}$ $\approx 8-10, \mathrm{Zr} / \mathrm{Hf})_{\mathrm{CN}}$ and $\left.\left.\mathrm{Nb} / \mathrm{Ta}\right)_{\mathrm{CN}} \approx 0.5-2, \mathrm{Th} / \mathrm{U}\right)_{\mathrm{CN}} \approx 5-10$ and high $\mathrm{Mg} / \mathrm{Fe}$. Most analyses show small positive $\mathrm{Sr}$ anomalies and negative $\mathrm{Y}$ anomalies of widely variable depth. Compared to coated and fibrous diamonds from other localities worldwide, they have high $\mathrm{Ba} / \mathrm{Th}, \mathrm{Ba} / \mathrm{K}$ and $\mathrm{K} / \mathrm{Sr}$, and anomalies in $\mathrm{Sr}$ and $\mathrm{Y}$ are rare in other fibrous diamonds.

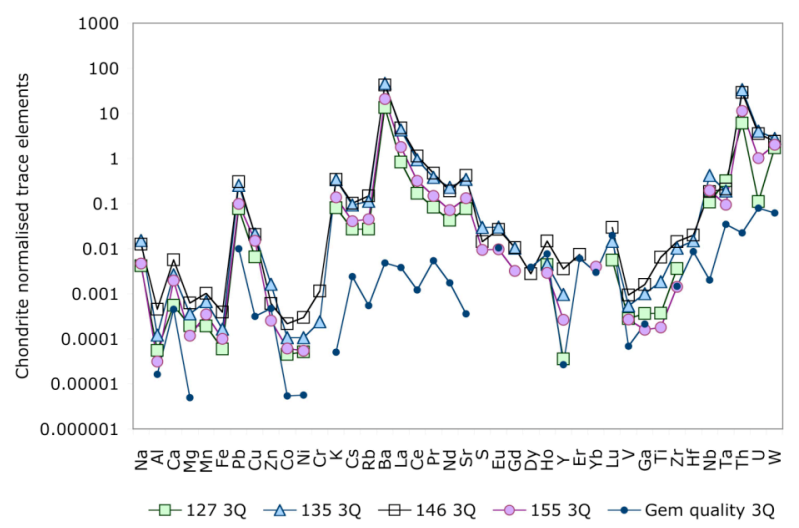

Figure 2. Chondrite-normalised trace-element patterns of coats on four representative diamonds from the A154 kimberlite. Shown for comparison are the third-quartile values for analyses of the gem-quality cores of coated stones.

\section{Trapped Melts and Fluids}

The Lac de Gras kimberlites contain xenoliths of megacrystalline garnet lherzolite derived from near the base of the lithosphere $(180-200 \mathrm{~km})$ beneath the Slave Craton, and Cr-diopside crystals within these xenoliths contain mm-sized round to oblate inclusions of quenched silico-carbonate melts (van Achterbergh et al. 2002, 2004). Detailed study of a large suite of these melt inclusions (Araujo et al., this conference, abstract A-00139) tracks the evolution of kimberlite-carbonatite melts, through fractionation of olivine and phlogopite and possible immiscible separation into carbonate-rich and silicate-rich melts. Despite wide variation in absolute abundances, the trace-element patterns of the different carbonatitic to silicic melts are broadly similar 
to one another, and to those of fibrous and coated diamonds from other localities (Fig. 3; cf Rege et al., 2005; Zedgenizov et al., 2007; Weiss et al., 2008). However, the Diavik diamond coats have higher LREE/HREE, $\mathrm{Ba} / \mathrm{La}, \mathrm{K} / \mathrm{La}$ and $\mathrm{Na} / \mathrm{Ca}$, and higher contents of chalcophile elements, than the quenched melt inclusions.

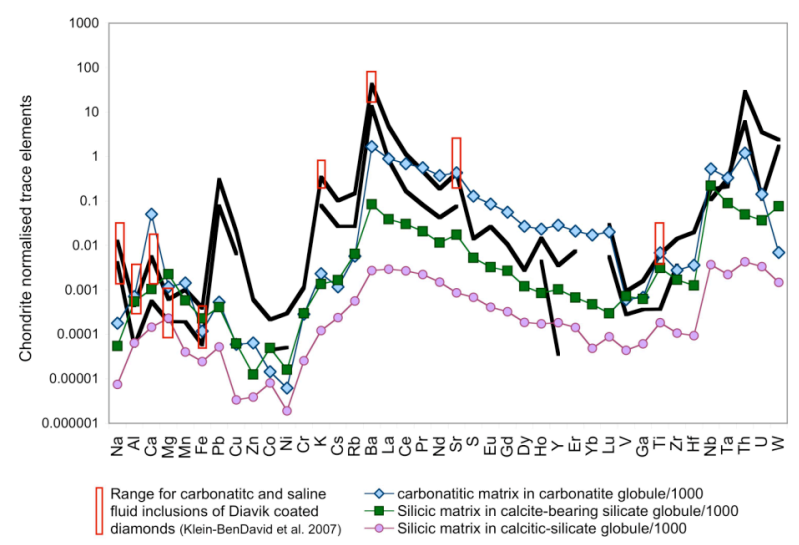

Figure 3. Trace-element patterns of quenched melt inclusions (/1000) in Cr-diopside of megacrystalline lherzolite xenoliths from the A154 kimberlite. High and low patterns of diamond coats from Fig. 2 are shown for comparison. Bars show ranges of concentration (/1000) in fluid inclusions from coats on Diavik diamonds; many $\mathrm{Sr}$ and $\mathrm{Ti}$ values are $<$ MDL (Klein-BenDavid et al., 2007).

“Major-element" ratios ( $\mathrm{Na}, \mathrm{Al}, \mathrm{Ca}, \mathrm{Mg}, \mathrm{Fe}, \mathrm{K}$, $\mathrm{Ba}, \mathrm{Ti})$ in the coats are closely similar to those measured (by EMPA) in individual fluid inclusions in diamond coats from the Diavik mines (Fig. 2; KleinBenDavid et al., 2007). Relative to the melt inclusions in the Cr-diopsides, the fluid inclusions in the diamond coats have high $\mathrm{Na} / \mathrm{Ca}, \mathrm{K} / \mathrm{Ca}$ and $\mathrm{Ba} / \mathrm{La}$. Comparison of absolute element abundances in the fluids and the diamond coats indicates that such fluid inclusions make up ca $1 \%$ by weight of the coats. These fluid inclusions lie in a spectrum from (dominantly) saline toward carbonatitic, suggesting that they may be genetically related to the silico-carbonatitic melts trapped in the Cr-diopside of the megacrystalline lherzolites.

Detailed analysis of the Cr-diopside adjacent to different types of melt inclusions shows pronounced metasomatic modification of the cpx, with introduction of LREE, Ba, K and Na. Modelled compositions for the metasomatising fluids, calculated using a variety of experimentally-derived values for $\mathrm{D}^{\text {cpx/fluid }}$ (Fig. 3) closely resemble both the LAM-ICPMS data for the diamond coats, and the measured compositions of the saline-carbonatite fluid inclusions. These observations suggest that similar fluids escaped from the carbonatitic to silicic melts to metasomatise the surrounding $\mathrm{Cr}$-diopside, following their trapping and the necking-down of the fluid-filled veins to produce the present rounded melt inclusions.

\section{Discussion and Conclusions}

The Diavik coated diamonds described here clearly reflect two generations of diamond growth, and the trace-element analyses suggest that the two generations formed from radically different metasomatic fluids. The accumulating trace-element data on fibrous and coated diamonds from localities worldwide suggests that most of these have crystallized from low-volume melts in the kimberlite-carbonatite spectrum (Rege et al., 2005; Zedgenizov et al., 2007; Weiss et al., 2008). The coats on the Diavik diamonds have more fractionated patterns than most fibrous diamonds, reflecting their growth from saline- fluids that evolved from such melts, rather than from the melts themselves. The data thus establish a genetic connection between the low-volume

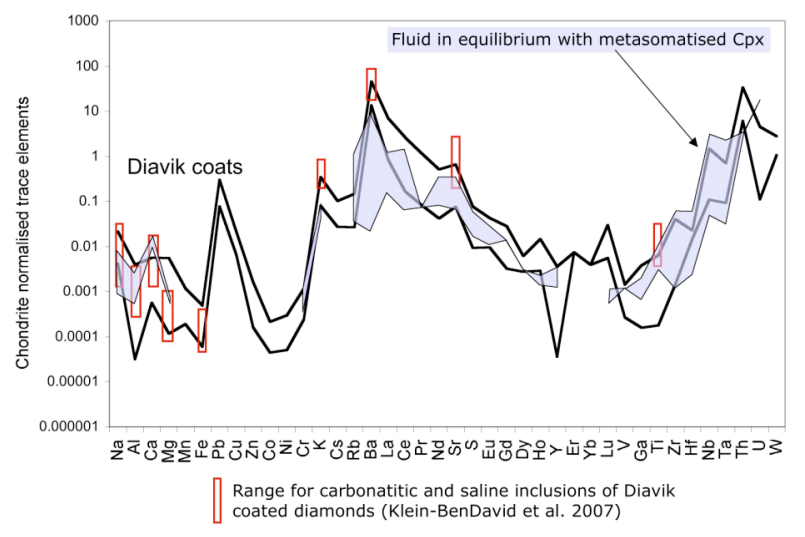

Figure 3. Calculated compositions of fluids (/1000) that metasomatised Cr-diopside adjacent to quenched melt inclusions, compared to patterns (/1000) of diamond coats and their fluid inclusions.

melts, the saline to carbonatitic fluids, and the coats on the Diavik diamonds. The Diavik situation is perhaps unique in preserving samples of both the melts (trapped and quenched within Cr-diopside) and the fluids that may have evolved from them (trapped within the coats on gem diamonds).

However, nearly all monocrystalline diamonds worldwide, including the octahedral cores of the diamonds described here, appear to have crystallized from fluids/melts that are distinctly different from those trapped in fibrous diamonds or coats on diamonds (e.g. Fig. 2). The relationship between the "monocrystalline-diamond" fluid and those that precipitated fibrous diamonds, diamondites (Rege et al., 2008) or the fibrous coats on monocrystalline diamonds remains to be clarified. It may involve the continued evolution of melts and fluids such as those described here. Alternatively, it may be a precursor $\left(\mathrm{CH}_{4}\right.$-rich) fluid, the oxidation of which produced $\mathrm{CO}_{2}$ and $\mathrm{H}_{2} \mathrm{O}$ that lowered the peridotite solvus and allowed production of melts in the kimberlite-carbonatite spectrum (Malkovets et al., 2007).

There are many unanswered questions arising from these data, but it is clear that quantitative, in situ analysis of trace elements in diamonds by LAMICPMS can provide unique information on the 
processes in the lithospheric mantle, including those by which diamonds are formed.

\section{References}

Klein-BenDavid, O,, Izraeli, E.S., Hauri, E., Navon, O., 2007. Fluid inclusions in diamonds from the Diavik mine, Canada and the evolution of diamond-forming fluids. Geochimica Cosmochimica Acta 71, 723-744.

Malkovets, V.G., Griffin, W.L., O’Reilly, S.Y., Wood, B.J., 2007. Diamond, subcalcic garnet and mantle metasomatism: Kimberlite sampling patterns define the link. Geology 35, 339-342.

Rege, S., Jackson, S.J., Griffin, W.L., Davies, R.M., Pearson, N.J., O'Reilly, S.Y., 2005. Quantitative trace element analysis of diamond by laser ablation inductively coupled plasma mass spectrometry. Journal of Analytical Atomic Spectroscopy 20,601-610.

Rege, S., Griffin, W.L., Kurat, G., Jackson, S.E., Pearson, N.J., O'Reilly, S.Y., 2008. Trace element chemistry of diamondites:
Crystallisation of diamond from kimberlitecarbonatite melts. Lithos (in press).

van Achterbergh, E., Griffin, W.L., Ryan, C.G., O'Reilly, S.Y., Pearson, N.J., Kivi, K., Doyle, B.J. 2002. A subduction signature for quenched carbonatites from the deep lithosphere. Geology 30, 743-746.

van Achterbergh, E., Griffin, W.L., O'Reilly, S.Y., Ryan, C.G., Pearson, N.J., Kivi, K., Doyle, B.J., 2004. Melt inclusions from the deep Slave lithosphere: implications for the origin and evolution of mantle-derived carbonatite and kimberlite. Lithos 76, 461-474.

Weiss, Y., Griffin, W.L., Elhlou, S., Navon, O., 2008. Comparison between LA-ICP-MS and EPMA analysis of trace elements in diamond. Chemical Geology (in press)

Zedgenizov, D.A., Rege, S., Griffin, W.L., Kagi, H., Shatsky, V.S., 2007. Compositional variations of micro-inclusions in fluid-bearing diamonds from Udachnaya kimberlite pipe as revealed by LA-ICP-MS. Chemical Geology 240, 151-162. 